1920 Svalbard Treaty;

Arctic; 2010 Treaty on the maritime areas delimitation and on the cooperation in the Barents Sea and in the Arctic Ocean; sea fishing; 200 Miles Fish Protection Area around Svalbard, marine living resources and their research; Joint Russian-Norwegian Fisheries Commission (SRNK); fishing rules and enforcement; quotas for catching marine living resources

\title{
Рыболовный Шпицберген
}

Академик МАНЭБ,

почетный доктор, профессор

В.К. Зиланов - Мурманский

государственный технический университет;

Д-р биол. наук

Д.Н. Клочков - ООО

«МОРИНФО» (г. Мурманск)

канд. биол. наук

B.Н. Шибанов - Москва

@vkzilan@mail.ru; info@mor-info.ru; persey100@mail.ru

Ключевые слова: Договор о Шпицбергене 1920 года; Арктика; Договор о разграничении морских пространств и сотрудничестве в Баренцевом море и Северном Ледовитом океане 2010 года; морское рыболовство; 200-мильная рыбоохранная зона Шпицбергена; морские живые ресурсы и их исследования; Смешанная российско-норвежская комиссия по рыболовству (СРНК); правила рыболовства и контроль за их исполнением; квоты на вылов водных биоресурсов

\section{FISHERY SPITSBERGEN}

Zilanov V.K., Doctor of Sciences, Professor - Murmansk State Technological University Klochkov D.N., Doctor of Sciences - "Morinfo" LLC

Shibanov V.N., PhD, vkzilan@mail.ru; info@mor-info.ru; persey100@mail.ru

The article analyzes the importance of marine fisheries in the area covered by the Svalbard Treaty of 1920, both for Russia and for other countries. The information on the history of the discovery and on marine living resources exploitation in the area is provided. The significant contribution of Russian scientists and fishermen to the trade is emphasized. Effective cooperation between Russia and Norway on fish resources monitoring and fisheries management in the framework of the SRNC was noted. At the same time, the disagreement between Russia and Norway regarding the introduction by Norway of a 200-mile fish protection zone around Spitsbergen necessitated Russia to adopt appropriate measures to ensure the national fisheries interests in the area.

Договору о Шпицбергене, который был подписан 9 февраля 1920 г. в Париже (далее по тексту Договор 1920г.), исполняется 100 лет. В то же время история рыболовства, китобойного и зверобойного промыслов в морском районе, прилегающем к архипелагу Шпицберген, островам Медвежий, Надежды и ряду других островов, насчитывает почти 1000 лет. По своему масштабу и значению для России и Норвегии вышеперечисленные виды промысла намного превосходят все другие направления экономической деятельности, осуществляемые на самом Шпицбергене, включая морской транспорт, добычу угля и туризм.

Обычно, говоря о Шпицбергене, имеют в виду, прежде всего, его сушу с прилегающими островами Медвежий, Надежды и ряд других более мелких островов и скал, а также прилегающие к ним территориальные воды. Между тем, морские районы, находящиеся в «шпицбергенском квадрате» (в соответствии с Договором1920 г. $-74-81^{\circ}$ с.ш. и 10 $35^{\circ}$ в.д.), по площади в десятки раз превышают площадь суши всех вместе взятых островов, включая сам Шпицберген (рuс.1). Именно 
эти морские районы являются местом активного рыболовства стран-участниц Договора 1920 года. Кроме рыболовства, в соответствии с Договором, осуществляются и иные виды деятельности.

Как известно, открытие и начало освоения архипелага Шпицберген и прилегающих к нему вод русскими поморами относится к XI-XII векам и тесно связано с морским промыслом, сначала морских млекопитающих - моржей, тюленей, а в последующем и рыб. Безусловно, определенное значение для колонистов имела охота на песцов, оленей, белых медведей непосредственно на островах.

И все же промысел морских живых ресурсов был тем движущим мотивом, который позволил поморам открыть и освоить суровые полярные острова, ранее именовавшиеся ими Грумант, и вести здесь различную хозяйственную деятельность, включая рыболовство. История освоения поморами, русскими, советскими исследователями архипелага Грумант-Шпицберген, других островов и вод, прилегающих к ним, и формирования правового режима морских районов, отражена в ряде научных, публицистических работ отечественных и зарубежных исследователей [1-46]. На основе этих работ и наших исследований выделены четыре основных периода, связанные с использованием морских живых ресурсов и формированием правового режима морского района Шпицбергена с прилегающими водами островов, подпадающих под действие Договора 1920 года.

Первый период связан с открытием архипелага и с развитием промысла морского зверя - моржей, тюленей, белых медведей и, попутно, рыбы. Наиболее интенсивно промысел осуществлялся в XV-XVII веках поморами и норвежцами. Это был период деятельности отдельных предпринимателей-одиночек и мелких артелей, которые на свой страх и риск вели здесь свою хозяйственную деятельность. Уже тогда на самом Шпицбергене поморы зимовали. В последующем не только зимовали, но оставались жить круглогодично. Так, русский промышленник Иван Старостин - один из самых первых постоянных жителей острова Западного Шпицберген, прожил здесь почти 39 лет.

Второй период начался в 1596 г. экспедицией голландца Виллема Баренца, открывшего архипелаг Шпицберген для европейцев и обнаружившего в его водах массовые скопления китов. После успешного проведения первой британской китобойной экспедиции к Западному Шпицбергену началось активное промышленное освоение запасов китов не только англичанами, но и немцами, шведами, норвежцами, голландцами, французами. Обработка забитых китов велась на побережье островов Западного и Южного Шпицбергена, где были установлены печи для вытапливания китового жира. Продукты китобойного промысла вывозились в европейские страны.

О масштабах этого промысла говорят следующие факты: в середине XVII века в промысле участвовало до 400 судов, а на побережье Западного Шпицбергена существовали многолюдные сезонные поселения и базы по переработке китов. Китобоям удавалось в отдельные годы добывать до 2600 морских млекопитающих. Конкурентная бесконтрольная охота, порой сопровождавшая «китовыми войнами», при-
В статье анализируется значение морского рыболовства в районе, подпадающем под действие Договора о Шпицбергене 1920 года, как для России, так и для других стран. Приводятся сведения об истории открытия и освоения в этом районе запасов морских живых ресурсов. Подчеркивается значительный вклад в это российских ученых и промысловиков. Отмечено эффективное сотрудничество России и Норвегии в рамках СРНК по мониторингу за рыбными ресурсами и управлению рыболовством. Вместе с тем, разногласия между Россией и Норвегией относительно введения Норвегией 200-мильной рыбоохранной зоны вокруг Шпицбергена обусловили необходимость принятия российской стороной соответствующих мер для обеспечения интересов отечественного рыболовства в этом районе.

вела к быстрому сокращению их запасов и сворачиванию этого, по тем временам, очень прибыльного дела. Архипелаг Шпицберген, его воды и прилегающие острова опустели. Активный китобойный промысел был закончен к 20-м годам XVIII века. Последний кит был официально добыт в районе архипелага в 1911 году.

Развитие китобойного промысла положило начало работам по картированию побережья архипелага.

И только на восточном, западном, и на южном побережье Шпицбергена, да и в их фьордах продолжали промысел русские поморы, обратив свое внимание, прежде всего, на рыбные запасы этих районов.

Третий период начался в конце XIX в., и связан с открытием и освоением рыбных запасов, формированием суверенитета архипелага Шпицберген с прилегающими островами и закладкой правовых основ эксплуатации ресурсов суши и морских районов. Продолжается он и в настоящее время - в XXI веке. Именно этот период стал ведущим в рыболовстве

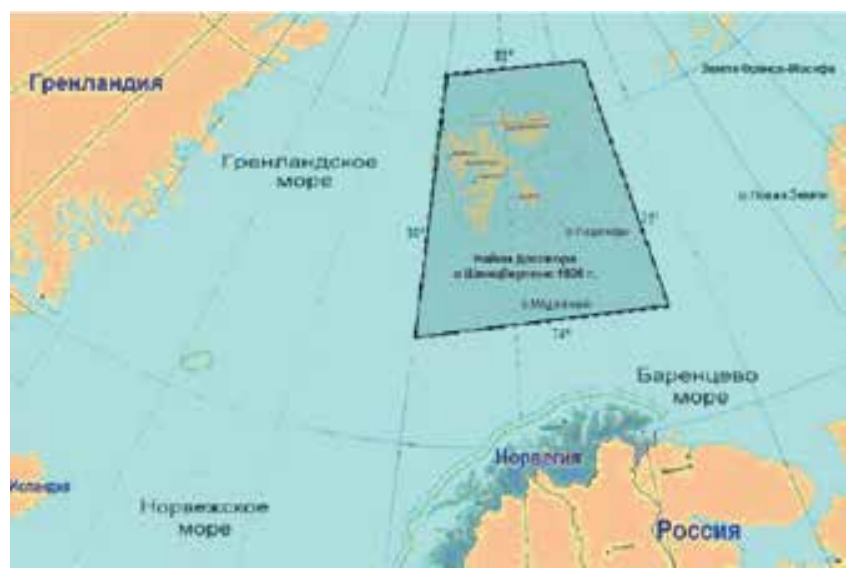

Рисунок 1. Границы архипелага Шпицберген, обозначенные в Договоре о Шпицбергене 1920 года

Figure 1. The borders of the Svalbard archipelago, as indicated in the 1920 Svalbard Treaty. 
России и Норвегии, как государств, наиболее близко расположенных к морским районам Шпицбергена, для прибрежного населения которых промысел рыбы имеет существенное значение.

До 1920 г. Шпицберген с прилегающими островами считался ничейной землей, хотя переговоры заинтересованных государств (России, Норвегии, Швеции, Дании, Великобритании, Германии и других) об их принадлежности велись длительный период в самых различных форматах. Они не привели к достижению взаимоприемлемого решения по правовому статусу Шпицбергена между всеми заинтересованными сторонами. Большинство стран тогда склонялось либо оставить его «ничейным», либо придать ему статус кондоминиума.

После окончания Первой мировой войны в Париже состоялась специальная конференция с участием девяти государств - США, Великобритании, Дании, Франции, Италии, Японии, Норвегии, Нидерландов и Швеции, на которой 9 февраля 1920 года был заключен Договор о Шпицбергене [10; 12; 24; 25; 28].

В статье 1 этого Договора был признан «полный и абсолютный суверенитет Норвегии над архипелагом Шпицберген, охватывающим с Медвежьим островом, или Берен-Эйланд, все острова, расположенные между 10 и $35^{\circ}$ восточной долготы от Гринвича и между 74 и $81^{\circ}$ северной широты... », но «на условиях, предусмотренных настоящим Договором». Эти условия были отражены в ряде статей Договора, прежде всего в статьях 2, 3 и 7, и касались они режима осуществления всех видов экономической деятельности, в том числе и рыболовства, на Шпицбергене, островах, подпадающих под действие Договора 1920 г. и в прилегающих к ним водах. Так, в статье 2 особо подчеркнуто, что «Суда и граждане Высоких Договаривающихся Сторон будут допущены на одинаковых условиях к осуществлению права на рыбную ловлю и охоту в местностях, указанных в статье 1 и в их территориальных водах».

Послереволюционная Россия, в период проведения Парижской конференции, не была признана всеми государствами, которые подписали Договор о Шпицбергене 1920 года и поэтому в ней не участвовала. Вместе с тем, государства - первоначальные участники Договора 1920 г. - хорошо понимали, что без присоединения к нему России он будет обречен на бездействие. В этой связи они предусмотрели в договоре специальное положение в статье 10, где было сказано, что «В ожидании того, что признание Высокими Договаривающими Сторонами русского правительства позволит России присоединиться к настоящему договору, русские граждане и общества будут пользоваться теми же правами, что и граждане Высоких Договаривающихся Сторон». Это положение основного текста Договора напрямую относит Россию к 9 государствам-основателям Договора о Шпицбергене, после ожидавшегося признания ее всеми участниками Договора. Такое произошло спустя 15 лет, в 1935 г., когда США, последними из 9 стран, подписавших договор, признали СССР, и наша страна присоединилась к Договору 1920 года. Современная Россия, как правопреемник СССР, является его участником и по настоящее время, что позволяет ей вести экономическую деятельность и рыболовство в этом морском районе, с учетом соответствующих положений Договора о Шпицбергене 1920 года, норм международного права и межправительственных соглашений и договоренностей, касающихся этого морского района, с рядом государств и, прежде всего, с Норвегией.

За 9 лет до присоединения СССР к Договору о Шпицбергене 1920 г., Президиум Центрального Исполнительного Комитета СССР Постановлением от 15 апреля 1926 г. объявил принадлежащими Советскому Союзу все территории в Северном Ледовитом океане в определенном секторе [12; 25; 22]. С запада он был ограничен меридианом $32^{\circ} 4$ ' $30^{\prime \prime}$ ' в.д. от Гринвича, проходящим до Северного полюса. С востока он ограничен меридианом $168^{\circ} 9^{\prime} 30^{\prime \prime}$ ' з.д., проходящим посередине пролива, разделяющего острова Ратманова и Крузенштерна, группы островов Диомида в Беринговом море. Против этого сектора, получившего наименование Полярных владений СССР и обозначавшегося на отечественных картах, да и ряде зарубежных карт, никто принципиально, в то время, не возражал. Между тем, его западная граница $\left(32^{\circ} 4^{\prime} 30^{\prime \prime}\right.$ в.д.) проходила намного западнее восточной границы Договора 1920 г. (35ํㅗ.д.). Западная граница Полярных владений СССР к северо-востоку от Шпицбергена даже проходила посередине территории острова Белый.

С присоединением в 1935 г. СССР к Договору о Шпицбергене западная граница Полярных владений СССР была приведена в соответствие с положениями этого Договора, т.е. перенесена с 32-го на $35^{\circ}$ восточной долготы. Этот сектор Полярных владений современной России в новых границах на западе действует и в настоящее время, поскольку его никто не отменял и не пересматривал. Мнение ряда исследователей о том, что со вступлением в силу Конвенции ООН по морскому праву 1982 года ряд ее положений якобы автоматически отменяет секторальные границы Полярных владений России, не могут быть признаны состоятельными [6; 27]. Во-первых, в Конвенции ООН по морскому праву 1982 года нет таких положений. И, во-вторых, даже если бы они были, все равно необходимо национальное решение, отменяющее Постановление ЦИК СССР от 15 апреля 1926 года. Такое решение отсутствует. Следовательно, граница Полярных владений России является действующей, что имеет определенное значение и для отечественного рыболовства в Арктике.

Таким образом, к 30 годам прошлого века в Западном секторе Арктики, включая морской район архипелага Шпицберген с прилегающими островами, сформировался такой правовой режим, который относил эти морские районы к открытой части Мирового океана, именуемой часто как международные воды. Ведение в них экономической деятельности, включая исследования и рыболовство, могли осуществлять все государства-участники Договора 1920 года. Таких государств в настоящее время 45.

Первые, наиболее значимые для российского Северо-Запада, рыбные ресурсы в водах архипелага Шпицберген с прилегающими островами были открыты в предвоенные годы, а освоение их относится к послевоенным годам [2; 13; 27; 31; 34]. Именно тогда ученые ПИНРО совместно с промысловиками 
Мурманска начали осваивать, прежде всего, запасы трески в районе острова Медвежий, а затем - и запасы сельди, которая, из-за своих крупных размеров и превосходных вкусовых качеств, получила в нашей стране наименование «полярный залом». Уже в 19311932 годах эти районы давали до 12\% годового улова трески в отечественном траловом промысле. Здесь же вели промысел и рыбаки Норвегии.

Приоритет открытия громадных скоплений крупной сельди и развития сельдяного промысла в Медвежинско-Шпицбергенском районе принадлежит советским ученым, поисковикам и промысловикам. За освоение промысла сельди - «полярного залома», ученые ПИНРО: профессор Ю.Ю. Марти, профессор Б.П. Мантейфель, капитан Г.П. Корольков и экономист С.В. Михайлов впервые в истории рыбной отрасли страны были удостоены Государственной (Сталинской) премии.

Поисково-исследовательские работы в этом районе были значительно расширены после окончания Второй мировой войны. Это привело в 50-60 годах прошлого века к открытию и освоению промыслом значительных запасов окуня-клювача, который был описан как новый вид морских окуней в 1951 г. ученым ПИНРО канд. биол. наук В.И. Травиным (Sebastes mentella Travin, 1951). В расширение районов промысла окуня-клювача большой вклад внесли капитаны-поисковики тралового флота и особенно капитан С.Д. Копытов. Его именем названа обширная территория промысла окуня в Баренцевом море - район Копытова. Так он обозначен не только на отечественных, но и на зарубежных промысловых картах и схемах.

В дальнейшем в районе к западу от о. Медвежий траулером «Треска», были обнаружены скопления черного палтуса. Это позволило начать здесь его специализированный траловый промысел. До этого черный палтус встречался только в качестве прилова при промысле трески и окуня. В результате широкомасштабных исследований биологии черного палтуса и его миграций, были открыты и освоены новые районы его промысла - вплоть до Западного Шпицбергена. Было доказано также единство его запасов, как и других объектов промысла, по всему Баренцеву морю, включая акваторию района Договора 1920 года, а также исключительных 200-мильных экономических зон (ИЭЗ) Норвегии и России (рuс.2).

Особое значение в рыболовстве в районе архипелага Шпицберген имела мойва в годы ее высокой численности. Так, в 1974-1984 гг. мойва была основным объектом промысла в Баренцевом море, что позволяло доводить ее годовой вылов до 400 тыс. т и более. Кроме упомянутых выше основных объектов рыболовства - трески, пикши, окуня, палтуса, сельди, мойвы - существенное значение для отечественного рыболовства имеют запасы камбаловых, путассу, морских зубаток, северной креветки, исландского гребешка и других морских живых ресурсов, многие из которых были открыты и освоены нашими соотечественниками. Все это позволило рыбакам России круглогодично вести промысел в районе, подпадающем под действие Договора 1920 года. За период с 1956 по 2018 гг. отечественный флот выловил здесь суммарно более 8 млн т рыбы. Наиболее результативными были первая половина 60-х и 80-е годы, когда ежегодный вылов был около 200 тыс. т, а в отдельные годы достигал более 400 тыс. тонн. В целом этот район дает до 20$25 \%$ годового улова рыбаков Севера России. В те годы, когда в результате охлаждения восточной части Баренцева моря основные скопления трески, пикши, окуня, палтуса имеют западное распределение, значение вод архипелага с прилегающими островами для отечественного рыболовства возрастает до 40-50\% от годового вылова России в Баренцевом море. Для сравнения: удельный вес этого

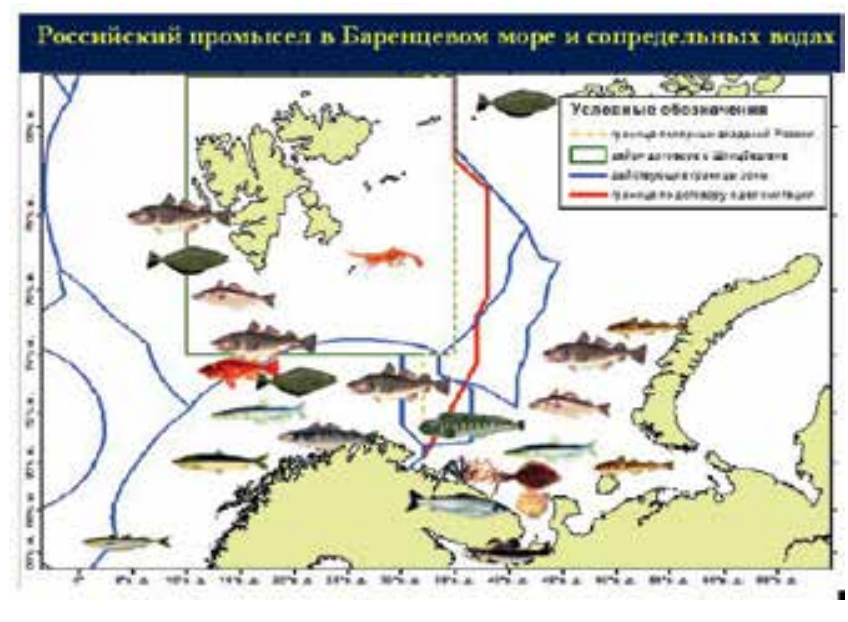

Рисунок 2. Российский промысел

в Баренцевом море и сопредельных водах

Figure 2. Russian fishing in the Barents Sea and adjacent waters

района в рыболовстве Норвегии составляет не более 8-10\% от годового вылова.

По принятому в России, в целях рыболовства, районированию Западного сектора Арктики, включая морской район архипелага Шпицберген и западную часть Баренцева моря, в него входят 10 рыбопромысловых районов. Это - Западный Шпицберген, Зюйдкапский желоб, Шпицбергенская банка, Западный склон Шпицбергенской банки, Южный склон Шпицбергенской банки, Медвежинская банка, Район Надежды, Западный желоб, Возвышенность Персея и Центральная возвышенность.

Норвегия применяет свою, исторически сложившуюся, систему районирования морского района архипелага Шпицберген с наименованием промысловых банок на норвежском языке.

В НЕАФК и в ИКЕС принято иное районирование, для учета вылова морских живых ресурсов и мониторинга за состоянием запасов, где этот обширный район имеет наименование - статистический район IIB. Однако в него не входит часть восточного морского района архипелага Шпицберген. Тем не менее, это районирование признается всеми странами, осуществляющими рыбный промысел в этом районе.

Как известно, Норвегия ввела в 1977 г. вокруг архипелага Шпицберген так называемую 200-мильную рыбоохранную зону. Советский Союз и в последующем Россия, как и ряд других государств, ее не при- 
знали, считая, что ее введение противоречит положениям Договора 1920 г. [12; 19; 20; 26; 27; 30]. На эту особенность в свое время, еще 15 июня 1977 г., обращало внимание Норвегии Правительство Советского Союза в соответствующей ноте МИД. В ней было сказано, что такой подход находится в «...несоответствии обязательствам, принятьм на себя Норвегией по Договору о Шпицбергене 1920 года» и что «...в этих условиях Советское правительство резервирует за собой возможность принятия соответствующих мер, обеспечивающих интересы СССР». Эта нота действует и по настоящее время, а Россия, как правопреемник СССР, осуществляет все права и обязанности, исходя из положений Договора о Шпицбергене 1920 года и из упомянутой ноты-заявления.

Дополнительный анализ обширных документов правового, исторического, природоохранного и другого характера за период с 1872 по 2015 гг. позволили отечественным исследователям [12; 18; 22] сделать следующие важнейшие выводы:

- Договор о Шпицбергене 1920 года не представляет оснований для установления Норвегией территориального моря, 200-мильной рыбоохранной, экономической или иной зоны Норвегии вокруг архипелага Шпицберген, также как и континентального шельфа здесь;

- Договор о Шпицбергене 1920 года не дает Норвегии прав в одностороннем порядке применять здесь меры по управлению ресурсами и осуществлять контрольные функщии без договоренности с другими государствами-участниками Договора о Шпицбергене. Не говоря уже о мерах принуждения и наказания по норвежским законам.

Выявлены и исследованы и ряд других важных положении, которые вытекают для данного района при осуществлении здесь рыболовства $[17 ; 18 ; 19 ; 20 ; 21$; $30 ; 41 ; 42]$.

Вместе с тем, Россия и Норвегия, как два прибрежных баренцевоморских государства, тесно сотрудничают по мониторингу за едиными запасами морских живых ресурсов и управлению рыболовством по всему Баренцевому морю, включая и морской район архипелага Шпицберген. Все возникающие вопросы рыболовства совместно рассматриваются россий-
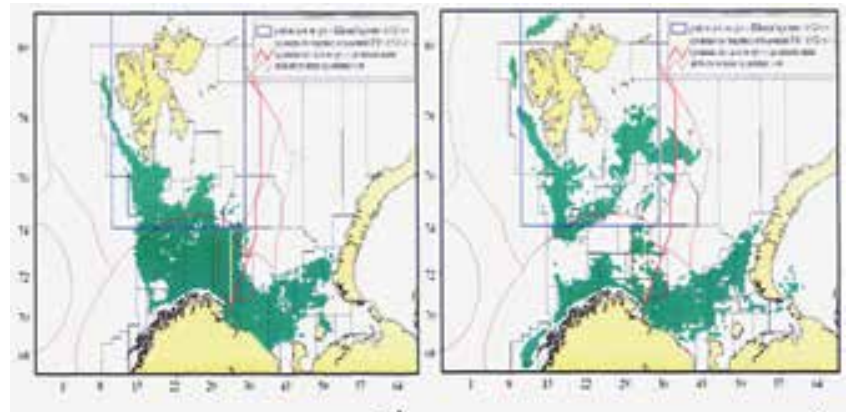

6)

\footnotetext{
Рисунок 3. Районы промысла морских живых ресурсов российскими рыболовными судами в Баренцевом море в холодные (а) и в теплые (б) годы

Figure 3. Fishing areas for marine living resources by Russian fishing vessels in the Barents Sea in the cold (a) and warm (b) years
}

ской и норвежской сторонами в рамках Смешанной Российско-Норвежской Комиссии по рыболовству (СРНК), что позволяет избегать конфронтации и вести рыбакам Норвегии и России промысел по отдельным запасам по единым согласованным правилам рыболовства [13; $14 ; 18 ; 19]$.

Мерами регулирования рыболовства, принятыми СРНК, руководствуются и рыбаки третьих стран, осуществляющих промысел морских живых ресурсов в морском районе архипелага Шпицберген. Все это создает долгосрочную основу для продолжения отечественного рыболовства в морском районе, подпадающем под действие Договора 1920 г. и в будущем.

Однако Норвегия проводит в этом районе, в соответствии с ее национальным законодательством, инспектирование как своих, так и иностранных судов, включая российские рыболовные суда, с целью контроля выполнения ими мер регулирования, принятых в рамках СРНК и на национальном уровне. Такие инспекщия и контроль часто ведут к конфликтам, которые не признаются российской стороной. Все попытки решить эту проблему пока не удаются, что сохраняет напряженность при рыболовстве в морском районе, подпадающем под действие Договора 1920 г. [12-16; 23; 27).

Позднее новые границы ИЭЗ и линии разграничения континентального шельфа между Норвегией и Россией были определены Договором между Российской Федерацией и Королевством Норвегия о разграничении морских пространств и сотрудничестве в Баренцевом море и Северном Ледовитом океане, заключенным 15 сентября 2010 года (Договор 2010 года). В нем в Приложении 1 отражены положения, в соответствии с которыми Россия и Норвегия будут и в дальнейшем сотрудничать в области рыболовства.

Анализ их все же показывает необходимость внесения соответствующих дополнительных поправок в Приложение 1 Договора 2010 года с тем, чтобы обеспечить отечественные интересы по рыболовству в морском районе, подпадающем под действие Договора 1920 г. [31; 39].

Последнее вытекает и из правового заключения Договора 2010 года, выполненного д-ром юрид. наук, профессором, заслуженным юристом России Г.М. Мелковым [23].В соответствии с этим заключением, после вступления в силу Договора 2010 г. наступают следующие негативные для России последствия для ее прав по Договору о Шпицбергене 1920 года:

- у России более не будет оснований возражать против 200-мильной зоны Норвегии вокруг Шпицбергена (а до Договора 2010 года такие основания были, согласно Договору о Шпицбергене 1920 года);

- у России более не будет оснований возражать против континентального шельфа Норвегии вокруг Шпицбергена (а до Договора 2010 года такие основания были, согласно Договору о Шпицбергене 1920 года);

- у России более не будет оснований возражать против территориального моря Норвегии вокруг Шпицбергена (а до Договора 2010 года такие основания были, согласно Договору о Шпицбергене 1920 года);

- всякая экономическая деятельность России, после вступления Договора 2010 года в силу, в морских 
районах вокруг Шпицбергена на основе Договора о Шпицбергене становится юридически невозможной. Такая деятельность возможна только при ее полном подчинении законодательству Норвегии о ее территориальном море, 200-мильной зоне, континентальном шельфе.

То есть тот факт, что в Договоре 2010 г. нет никакого упоминания, ссылки на подтверждение прав России по Договору о Шпицбергене 1920 г., соответствует интересам Норвегии, но не России. Статьи 1, 2 и 3 Договора о Шпицбергене 1920 года дают огромные права России: например, на равных с Норвегией и другими участниками Договора 1920 года заниматься рыбным промыслом, добычей минеральных ресурсов не только в обозначенных координатах района действия Договора о Шпицбергене, но и на самих островах, которые находятся под суверенитетом Норвегии. Если оставить всё так, как есть в Договоpe 2010 г., без каких-либо изменений и дополнений в самом Договоре и в Приложениях 1 и 2 к нему, то следующим шагом Норвегии будет преобразование 200-мильной рыбоохранной зоны в 200-мильную экономическую зону вокруг Шпицбергена. А это, в свою очередь, нанесет не только огромный экономический ущерб России, но и большой политический ущерб, так как может вызвать целую цепочку притязаний к России в других районах.

Наряду с этим сохраняются и различные подходы России и Норвегии относительно правового статуса морского района, описанного в Договоре 1920 года. Россия продолжает его считать районом открытого моря, а Норвегия - районом, находящимися под ее юрисдикцией (puc. 4, 5). Такое принципиальное расхождение в правовой оценке морских районов архипелага Шпицберген создает определенную напряженность в двусторонних отношениях между Россией и Норвегией, как единственных прибрежных государств Баренцева моря. Более того, это сказывается и на осуществлении здесь рыболовства российскими судами. Попытки России урегулировать эти противоречия пока не привели к взаимоприемлемому решению. В этих условиях морской район рыболовства вокруг архипелага Шпицберген является одним из сложнейших, с правовой точки зрения, в Западном секторе Арктики с высокой вероятностью возникновения конфликтных ситуаций. Предотвратить их - задача Норвегии и России, которые в наибольшей степени заинтересованы в долгосрочном использовании в этом районе морских живых ресурсов, на основе научных рекомендаций и с учетом единого экологического комплекса по всему Баренцевому морю [13; 29]. Это принципиальное положение Россия подтвердила в Заявлении Государственной Думы Федерального Собрания Российской Федерации, сделанном 25 марта 2011 г. при ратификации Договора 2010 года (Приложение). Особо в Заявлении подчеркивается приверженность России соблюдению положений Договора о Шпицбергене 1920 года, Конвенции ООН по морскому праву 1982 года.

Не менее важны для развития сотрудничества между сторонами и такие базисные межправительственные Соглашения как, касающиеся сотрудничества России и Норвегии в области рыболовства от 1975 г. и о взаимных отношениях в области рыбо-

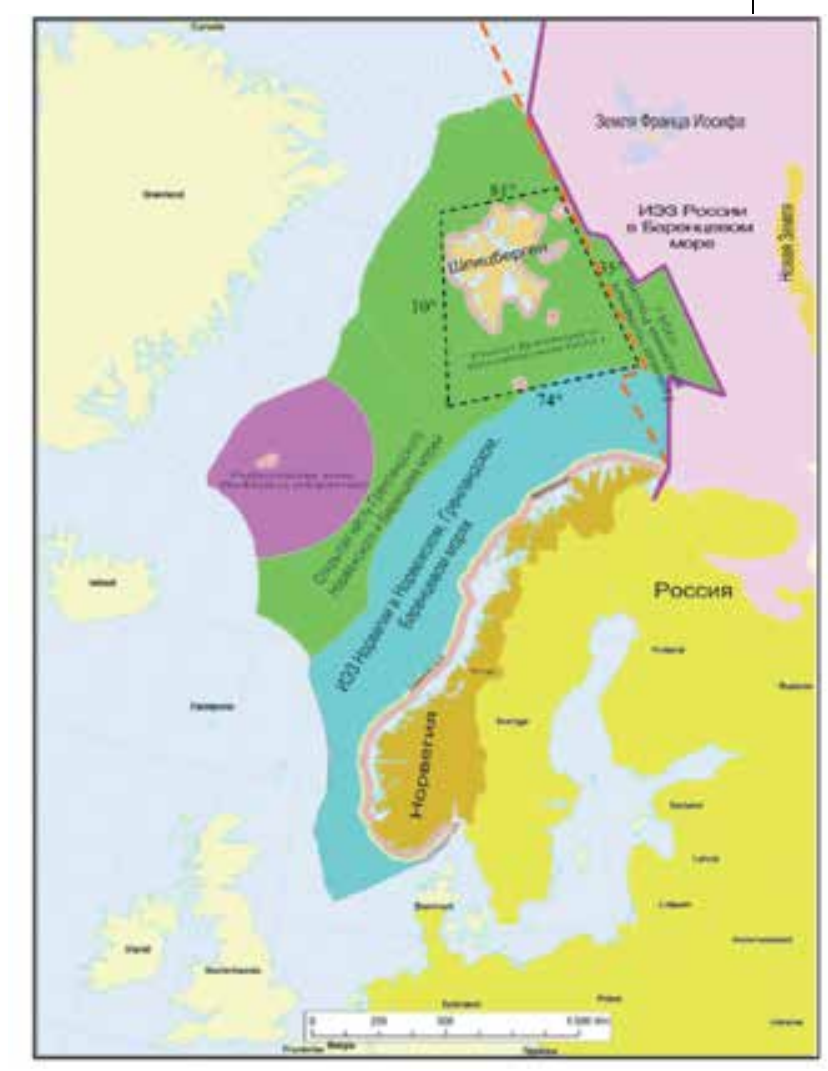

Рисунок 4. Доктринальная позиция России относительно морских пространств,

касающихся промысла морских живых ресурсов (за исключением "сидячих видов") в Баренцевом, Гренландском и Норвежском морях

Figure 4. Russia's doctrinal position on marine spaces related to the harvesting of marine living resources (excluding "sedentary species") in the Barents, Greenland and Norwegian Seas

ловства от 1976 г., а также, разработанных для их реализации, механизмов, включая СРНК.

Со вступлением в силу Договора 2010 г. рыбопромысловые суда под флагом Российской Федерации пока продолжают промысел морских живых ресурсов в морском районе Шпицбергена в счёт своей национальной квоты, принятой в рамках СРНК, поскольку морской район вокруг Шпицбергена рассматривается Россией как район открытого моря (рuс.4). Точка зрения Норвегии другая: вокруг Шпицбергена была и существует, несмотря на Договор 2010 года, 200-мильная норвежская рыбоохранная зона со всеми вытекающими последствиями для рыболовного флота России (рuс.5).

Одновременно с этим капитаны российских рыболовных судов, в соответствии с указаниями Росрыболовства от 27 июня 2011 г. и от 10 апреля 2013 г. «О разъяснении капитанам российских судов» (далее по тексту «Разъяснениями») предписан следующий порядок при инспектировании норвежцами наших судов: Продолжать, как и до вступления в силу Договора 2010 года, допускать на борт норвежских инспекторов Береговой охраны (KYSTVAKT, более известна рыбакам, как БОХР), входящих в Вооружённые силы Норвегии, для проверки выполнения мер регулиро- 


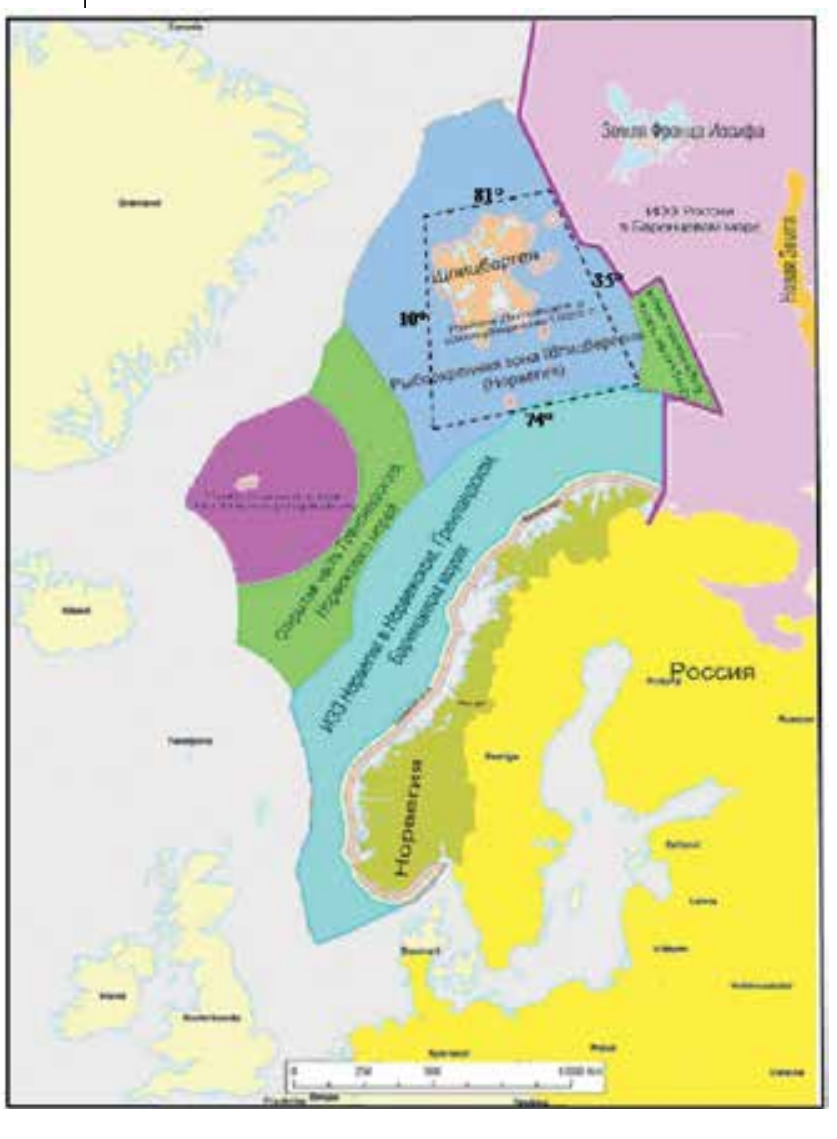

Рисунок 5. Доктринальная позиция Норвегии относительно морских пространств, касающихся промысла морских живых ресурсов (за исключением "сидячих видов") в Баренцевом, Гренландском и Норвежском морях

Figure 5. Norway's doctrinal position regarding marine spaces related to the harvesting of marine living resources (excluding "sedentary species") in the Barents, Greenland and Norwegian Seas

вания рыболовства, принятыми СРНК, и действующего для морского района Шпицбергена [12; 28; 29]. По результатам таких проверок, как правило, норвежские инспектора составляют протоколы, которые капитаны российских рыболовных судов, в соответствии с упомянутыми выше «Разъяснениями», не подписывают, сообщая об этом своему судовладельцу. В тех случаях, когда, по мнению норвежских инспекторов, имеются подозрения или выявлены нарушения правил рыболовства (они принимаются для этого районными норвежскими властями), судно задерживается и осуществляется разбирательство. При невозможности выявления всех обстоятельств нарушений на месте, судно конвоируется в норвежский порт, где проводится дополнительное рассмотрение дела уже в норвежских судах в соответствии с норвежскими законами. Такие задержания - аресты российских рыболовных судов в морском районе Шпицбергена - происходят регулярно. В последние годы действия Договора 2010 года. таких задержаний, как правило, бывает от 1 до 3 судов в год.

Что же касается проверок российских рыбопромысловых судов норвежскими инспекторами БОХР в морском районе Шпицбергена, то ими охвачено почти $100 \%$ судов. Как правило, большинство судов инспектируются по 2-3 раза в период нахождения их на промысле. После каждой такой проверки капитан судна получает письменное предупреждение о последствиях неподачи норвежским властям ежедневных сведений о местонахождении, вылове и т.д. при работе в 200-мильной норвежской рыбоохранной зоне Шпицбергена и требование подписать это предупреждение. Последнее капитанами отвергается со ссылкой на «Разъяснения»; информация об этом направляется судовладельцу.

Все предложения российской стороны урегулировать эти острые конфликтные ситуации, выработав согласованные совместные процедуры контроля и проверок мер регулирования рыболовства, отвергаются норвежцами как затрагивающие их юрисдикцию в этом районе. Со вступлением в силу Договора 2010 г. у норвежской стороны появились дополнительные аргументы в свою пользу по этому вопросу: прежде всего то, что по Договору (Статья 2) Россия признала юрисдикцию и суверенные права Норвегии к западу от линии разграничения, куда также входит и 200 -мильная рыбоохранная зона Шпицбергена. Именно этот вопрос - признание нами прав Норвегии на морской район Шпицбергена и обеспечение оптимальных условий для работы отечественного флота в нём, в условиях вступления в силу Договора 2010 г., - был одним из ключевых при принятии решения депутатами и сенаторами Федерального Собрания Российской Федерации о его ратификации. Не получив по этому вопросу убедительной аргументации в ходе открытого Пленарного заседания Госдумы от официального представителя Президента Российской Федерации, заместителя министра иностранных дел В.Г. Титова, депутаты всё же приняли решение о ратификации Договора (напомню, голосами только одной фракщии), сопроводив его Заявлением «В связи с разграничением морских пространств между Российской Федерацией и Норвегией в Баренцевом море и Северном Ледовитом океане» (см. Приложение А). В нём законодатели, констатировав основные положения Договора 2010 года и выразив надежду на возможное дальнейшее укрепление двухстороннего сотрудничества, после вступления его в силу, особо отмечают важность при этом не нанесения «какого-либо ущерба правам и обязанностям Сторон по другим международным договорам», к которым «безусловно, относится и Договор о Шпицбергене 1920 года». Этим, единственным из всех официальных документов, относящихся к Договору 2010 года, упоминанием о важности для российской ресурсной деятельности морского района, подпадающего под действие Договора о Шпицбергене 1920 года, парламентарии России посылают важный сигнал норвежской стороне о необходимости с этим считаться и учитывать при сотрудничестве в этом районе [26; 33]. Не менее существенно и то, что в связи со 100-летием Договора о Шпицбергене, Министр иностранных дел Российской Федерации С.В. Лавров, в своем послании Министру иностранных дел Королевства Норвегия И.М. Эриксен Сёрэйде от 4 февраля 2020 года, особо подчеркнул о «...неправомерности установления Норвегией так называемой «рыбоохранной зоны», искусственное расширение природоохранных зон для ограничения экономической деятельности... (Приложение «Б»). 
В настоящее время начинается четвертый исторический период в Западном секторе Арктики, включая морской район Договора 1920 года, который достигнет пика, вероятно, в середине XXI века. Он будет обусловлен разведкой и разработкой углеводородов - нефти и газа - не только на территории самих островов, но и на акватории участков шельфа, подпадающих под действие Договора 1920 года. Разведка и разработка запасов углеводородов на шельфе приведут к необходимости поиска правовых основ для такой деятельности в рамках положений Договора 1920 года. Будет необходимо также решение ряда природоохранных и экологических проблем, прежде всего - гармонизация двух видов экономической деятельности - рыболовства и нефтегазовой промышленности. В этой связи морской район архипелага Шпицберген, с точки зрения его значения для отечественного рыболовства, становится особенно важным для выработки подходов по защите национальных интересов, с учетом природоохранного аспекта в Западном секторе Арктики и завершающимся здесь разграничением не только 200-милных ИЭЗ, но и континентального шельфа (рuс.6).

Сотрудничество России и Норвегии по мониторингу за морскими живыми ресурсами и управлению рыболовством в Западном секторе Арктики, включая район, подпадающий под действие Договора 1920 года, характеризуется эффективностью и высоким доверием между сторонами. Этому способствуют сбалансированные межправительственные соглашения в области рыболовства и механизмы по их практической реализации. К последнему относится, прежде всего, СРНК. Интересам России и Норвегии отвечают сохранение высокого уровня сотрудничества в будущем и препятствование ННН-рыболовству со стороны третьих стран.

Вместе с тем серьёзные разногласия между Россией и Норвегией по правовому статусу морских районов архипелага Шпицберген остаются не урегулированными, что создает здесь конфликтную ситуацию, которая может вызвать нежелательные последствия для рыболовства обеих сторон.

Исходя из вышеприведённого и принимая во внимание возможность внесения поправок в Приложение 1 Договора 2010 года, своевременным было бы, с учётом практики применения этого Договора в последние годы, осуществление следующих дополнительных мер по обеспечению интересов отечественного рыболовства в морском районе, подпадающем под действие Договора 1920 года:

1. Провести российско-норвежские переговоры относительно внесения поправок в Приложение I Договора 2010 года, касающиеся вопросов рыболовства, которые бы обеспечивали долгосрочные интересы отечественного рыболовства в Западном секторе Арктики, включая морской район, подпадающий под Договор о Шпицбергене 1920 года.

2. Информировать Норвегию о том, что до принятия поправок в Приложение I российские суда продолжат осуществлять рыбный промысел в морском районе архипелага Шпицберген, как они ведут его и в настоящее время, с соблюдением мер регулирования и правил рыболовства, принятых СРНК.
3. Контроль деятельности рыболовных судов под флагом России должен осуществляться в морском районе архипелага Шпицберген только российскими компетентными органами.

4. Перспективным представляется продолжение специальных российско-норвежских переговоров по выработке и принятию единых мер регулирования и правил рыболовства, гармонизированных процедур проверки их исполнения как российскими, так и норвежскими инспекторскими судами, а также-мер наказания, в случае их нарушения по всем промысловым районам Баренцева моря, независимо от зон юрисдикции.

5. Направить норвежской стороне Заявление Государственной Думы России, которое было принято ею при ратификации Договора 2010 года, о неиз-

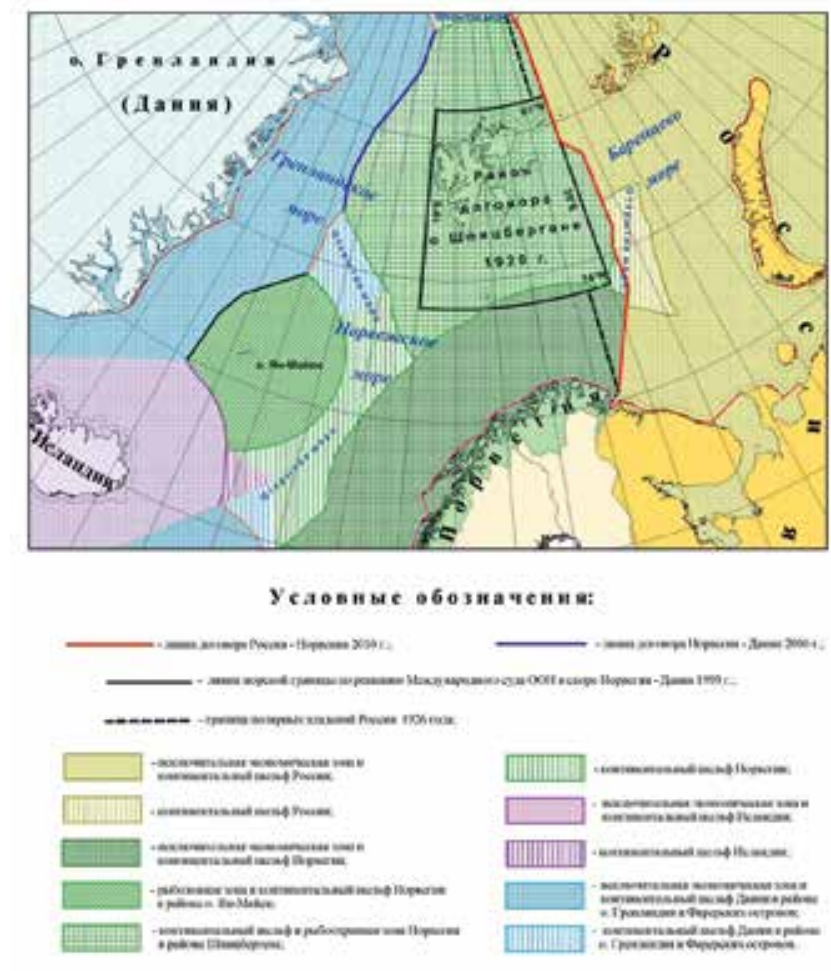

Рисунок 6. Пространственное положение различных зон, районов юрисдикции в Баренцевом, Норвежском и Гренландском морях и линия разграничения по Договору 2010 года

Figure 6. The spatial position of the various zones, areas of jurisdiction in the Barents, Norwegian and Greenland Seas and the demarcation line under the 2010 Treaty

менности позиции России по неукоснительному соблюдению Договора о Шпицбергене 1920 года и непризнании нами, как и ранее, так называемой норвежской 200-мильной рыбоохранной зоны, введённой вокруг архипелага Шпицберген.

6. Разработать и принять на национальном и международном уровнях специальные экологические требования для разведки и разработки углеводородных ресурсов в Западном секторе Арктики, включая морской район архипелага Шпицберген и шельф Баренцева моря. При этом следует отдать 
предпочтение сохранению традиционного рыболовства, окружающей среды, видового разнообразия и генофонда морских живых ресурсов.

7. Выступить с инициативой создания на Шпицбергене российско-норвежского Центра мониторинга состояния морских живых ресурсов и контроля деятельности рыбопромысловых судов в Западном секторе Арктики, морском районе архипелага Шпицберген, в Баренцевом, Гренландском, Норвежском морях и Международного арбитражного суда по спорам, связанным с экономической деятельностью в морском районе, подпадающем под действие Договора 1920 года.

ПРИЛОЖЕНИЕ А

Государственная Дума Федерального Собрания Российской Федерации пятого созыва

Постановление om 25 марта 2011 г. № 5030-5 ГД

О Заявлении Государственной Думы Федерального Собрания Российской Федерации «В связи с разграничением морских пространств между Российской Федерацией и Норвегией в Баренцевом море и северном Ледовитом океане»

Государственная Дума Федерального Собрания Российской Федерации постановляет:

1. Принять Заявление Государственной Думы Федерального Собрания Российской Федера- ции «В связи с разграничением морских пространств между Российской Федерацией и Норвегией в Баренцевом море и Северном Ледовитом океане».

2. Направить настоящее Постановление и указанное Заявление Президенту Российской Федерации Д.А. Медведеву, в Правительство Российской Федерации, Общественную палату Российской Федерации.

3. Направить настоящее Постановление и указанное Заявление в «Парламентскую газету» для официального опубликования.

4. Настоящее Постановление вступает в силу со дня его принятия.

Председатель Государственной Думы Федерального Собрания Российской Федерации Б.В. Грызлов
Государственная Дума Федерального Собрания Российской Федерации пятого созыва

Заявление от 25 марта 2011 г. в связи с разграничением морских пространств между Российской Федерацией и Норвегией в Баренцевом море и северном Ледовитом океане

Государственная Дума Федерального Собрания Российской Федерации считает, подписанный в присутствии глав государств, Договор между Российской Федерацией и Королевством Норвегия о разграничении морских пространств и сотрудничестве в Баренцевом море и Северном Ледовитом океане (далее - Договор) - значительным событием в новейшей отечественной истории, завершающим более чем сорокалетний переговорный период между двумя государствами и открывающим дополнительные возможности для сотрудничества Сторон в эксплуатации природных ресурсов этого обширного морского района, а также в мирном освоении Арктики.

Договором, ратифицированным Государственной Думой, на основе общепризнанных принципов и норм международного права определяются суверенные права и юрисдикция Российской Федерации и Норвегии в отношении морских пространств общей площадью около 175 тыс. кв. км.

Принципиально важно, что при этом не наносится какого-либо ущерба правам и обязательствам Сторон по другим международным договорам, участниками которых являются Российская Федерация и Королевство Норвегия. К таким международным договорам, безусловно, относятся и Договор о Шпицбергене 1920 года, и Конвенция ООН по морскому праву 1982 года. Сохраняют свое действие такие основополагающие договоры, обеспечивающие сотрудничество Сторон в сфере рыболовства как Соглашение между Правительством Союза Советских Социалистических Республик и Правительством Королевства Норвегии о сотрудничестве в области рыболовства 1975 года, Соглашение между Правительством Союза Советских Социалистических Республик и Правитель- ством Королевства Норвегии о взаимных отношениях в области рыболовства 1976 года.

Со вступлением в силу Договора должны укрепиться основы двустороннего сотрудничества Российской Федерации и Норвегии, в том числе в комплексном развитии северных регионов двух государств, в рыбопромысловой деятельности, где сложились уникальные в мировой практике механизмы согласования взаимовыгодных решений и в эксплуатации трансграничных месторождений углеводородов.

Важно, чтобы заложенные в Договоре принципы совместного освоения и распределения природных ресурсов, а также эффективные процедуры урегулирования возможных споров были на практике обеспечены принятием устойчивых и ответственных решений в этой области.

Депутаты Государственной Думы исходят из того, что, после вступления Договора в силу, режим совместного управления общими рыбными запасами, включая деятельность Смешанной Российско-Норвежской комиссии по рыболовству, будет сохранен и упрочен, а также из того, что Правительство Российской Федерации будет и далее принимать все необходимые меры по обеспечению законных прав и интересов отечественной рыболовной отрасли и неукоснительного соблюдения, закрепленного Договором, базового принципа отношений Российской Федерации и Норвегии в сфере рыболовства после разграничения морских пространств. Договор не должен негативно влиять на возможности каждой из Сторон в области рыболовства.

Государственная Дума убеждена в том, что завершение процесса разграничения морских пространств между Российской Федерацией и Норвегией в Баренцевом море и Северном Ледовитом океане окажет положительное воздействие на общую ситуацию в Арктическом регионе и станет конструктивным вкладом в укрепление правового режима Арктики, поддержание мира, взаимопонимания и сотрудничества в этом стратегически важном регионе.

Председатель Государственной Думы Федерального Собрания Российской Федерации Б.В. Грызлов 


\section{ПРИЛОЖЕНИЕ Б}

О послании Министра иностранных дел России

С.В.Лаврова Министру иностранных дел Норвегии И.М.Эриксен Сёрэйде по случаю 100-летия подписания Договора о Шпицбергене 04-02-2020 2.https://www.mid.ru/foreign_policy/news/-/ asset-publisher/cKNonkJE02Bw/content/id/4019093

\section{СООБЩЕНИЕ ДЛЯ СМИ}

В связи со 100-летним юбилеем Договора о Шпицбергене, подписанного 9 февраля 1920 г. в Париже, Министр иностранных дел Российской Федерации С.В.Лавров направил послание главе МИД Норвегии И.М.Эриксен Сёрэйде.

В послании отмечается, что Договор о Шпицбергене 1920 г. является важным многосторонним документом, определившим уникальный правовой статус архипелага. Признав норвежский суверенитет над Шпицбергеном, Договор гарантировал права и законные интересы других государствучастников этого международного соглашения, включая Россию. Его подписание заложило основы для сотрудничества заинтересованных государств в целях развития и использования обширной территории архипелага. Традиции мирного сосуществования и добрососедства не прерывались даже в годы «холодной войны» и сохраняются в целом по сей день. На архипелаге активно развивается наука и образование. Угледобыча, являвшаяся на протяжении многих лет основой хозяйственной деятельности на Шпицбергене, всё в большей степени дополняется туризмом и сферой услуг.
Вместе с тем российской стороной в послании была вновь подчёркнута необходимость соблюдения Норвегией духа и буквы Договора 1920 г. в части обеспечения «одинакового свободного доступа» на архипелаг и возможностей ведения там хозяйственноэкономической деятельности «на условиях полного равенства». Озабоченность у нас, в частности, вызывают введенные ограничения на использование российского вертолёта, направленный исключительно против наших граждан порядок депортации со Шпицбергена, неправомерность установления Норвегией так называемой «рыбоохранной зоны», искусственное расширение природоохранных зон для ограничения экономической активности на архипелаге, ряд других проблем.

На Шпицбергене Россия - единственная, кроме Норвегии - осуществляет хозяйственную деятельность на протяжении многих десятилетий и не намерена сворачивать свое присутствие. Напротив, имеются долгосрочные планы его укрепления, диверсификации и модернизации. Российская Федерация заинтересована в выстраивании долгосрочного и конструктивного взаимодействия с Норвегией на Шпицбергене, развитии диалога в решении практических вопросов.

Норвежским партнерам предложено провести двусторонние консультации для устранения ограничений в деятельности российских структур на архипелаге. Ожидаем позитивного ответа норвежской стороны.

\section{ЛИТЕРАТУРА И ИСТОЧНИКИ}

1. Адров Н.М. Исследования Баренцева моря за 1000 лет. - Мурманск Пресс, 2002. 186 c.

1. Adrov N.M. Issledovaniya Barenceva morya za 1000 let. - Murmansk: Press, 2002. $186 \mathrm{p}$.

2. Исследования ПИНРО в районе архипелага Шпицберген. /Отв. ред. Шевелев М.С. Мурманск: ПИНРО, 2004. 543 с.

2. Issledovaniya PINRO $\mathrm{v}$ rajone arhipelaga SHpicbergen. /Otv. red. SHevelev M.S. Murmansk: PINRO, 2004. 543 p.

3. Арлов Т.Б. История архипелага Шпицбергена / Тур Б. Арлов (перевод с норвежского Е. Дневой, А. Комповой), - М. Паулсен, 2016. 592 с.,202 илл.

3. Arlov T.B. Istoriya arhipelaga SHpicbergena / Tur B. Arlov (perevod s norvezhskogo E. Dnevoj, A. Kompovoj), - M. Paulsen, 2016. 592 p.,202 ill. 4. Губанов А.И. Разграничение континентального шельфа в Арктике: международно-правовые проблемы и перспективы -М.: «Зеркало-М», 2015. 312 c.

4. Gubanov A.I. Razgranichenie kontinental'nogo shel'fa v Arktike: mezhdunarodno-pravovye problemy i perspektivy -M.: «Zerkalo-M», 2015. 312 p.

5. Зингер Е.М. Шпицберген - ледовый архипелаг. - М.: Пента, 2006. $302 \mathrm{c}$.

5. Zinger E.M. SHpicbergen - ledovyj arhipelag. - M.: Penta, 2006. 302 p. 6. Зиланов В.К. Арктическая рыба на столе Меркурия // Мурманск. Мурманская миля № 3, 2014. С. 12-15.

6. Zilanov V.K. Arkticheskaya ryba na stole Merkuriya // Murmansk. Murmanskaya milya № 3, 2014. pp. 12-15.

7. Михайлов И.А. Архипелаг Шпицберген. Перекресток событий и судеб. - М.: Научный мир, 2004. 253 с.

7. Mihajlov I.A. Arhipelag SHpicbergen. Perekrestok sobytij i sudeb. - M.: Nauchnyj mir, 2004. 253 p.

8. Печуров А.В. Шпицберген. - М.: Юрист, 1983. - 186 с.

8. Pechurov A.V. SHpicbergen. - M.: YUrist, 1983. - 186 p.

9. Тимченко Л.Д. Шпицберген: история и современность. - Харьков: Феникс, 1992. 214 с.

9. Timchenko L.D. SHpicbergen: istoriya i sovremennost'. - Har'kov: Feniks, 1992. 214 p.

10. Фифе Р.Э. Предмет и цели Договора о Шпицбергене (Свальбард) с точки зрения международного морского права. // Московский журнал международного права. № 4.2004.

10. Fife R.E. Predmet i celi Dogovora o SHpicbergene (Sval'bard) s tochki zreniya mezhdunarodnogo morskogo prava. // Moskovskij zhurnal mezhdunarodnogo prava. № 4. 2004.

11. Деканозов Р.В. Соглашение 1872 года о Шпицбергене. / «Вопросы теории советского права». Новосибирск: Деловая книга, 1966. 210 c.

11. Dekanozov R.V. Soglashenie 1872 goda o SHpicbergene. / «Voprosy teorii sovetskogo prava». Novosibirsk: Delovaya kniga, 1966. 210 p.

12. Вылегжанин А.Н. Правовой режим Шпицбергена и прилегающих морских районов/А.Н. Вылегжанин, В.К. Зиланов, В.М. Савва; отв. Ред. А.Н. Вылегжанин. - М., Норма, 2019. 308 с.

12. Vylegzhanin A.N. Pravovoj rezhim SHpicbergena i prilegayushchih morskih rajonov/A.N. Vylegzhanin, V.K. Zilanov, V.M. Savva; otv. Red. A.N. Vylegzhanin. - M., Norma, 2019. 308 p.

13. Сэтра Г. 60 лет российско-норвежскому сотрудничеству в области морских исследований. // Рыбное хозяйство. 2018. №4. С. 3-7.

13. Setra G. 60 let rossijsko-norvezhskomu sotrudnichestvu v oblasti morskih issledovanij. // Rybnoe hozyajstvo. 2018. №4. pp. 3-7.

14. Зиланов В.К. Единство экологического комплекса северных морей как основа сотрудничества Советского Союза и Норвегии в области сохранения и оптимального использования морских живых ресурсов. - М.: ВНИРО, Сборник научных трудов. 1989. 351 с.

14. Zilanov V.K. Edinstvo ekologicheskogo kompleksa severnyh morej kak osnova sotrudnichestva Sovetskogo Soyuza i Norvegii v oblasti sohraneniya i optimal'nogo ispol'zovaniya morskih zhivyh resursov. - M.: VNIRO, Sbornik nauchnyh trudov. 1989. 351 p.

15. Зиланов В.К., Лука Г.И., Шлейник В.Н., Ушаков Н.Г. О рациональной эксплуатации запасов мойвы Баренцева моря. // Рыбное хозяйство -1984. №7. 9 с.

15. Zilanov V.K., Luka G.I., SHlejnik V.N., Ushakov N.G. O racional'noj ekspluatacii zapasov mojvy Barenceva morya. // Rybnoe hozyajstvo -1984. №7. 9 p.

16. Зиланов В.К. Россия - Норвегия: возможности интеграции. // Рыбное хозяйство. 1999. № 6. С.17-19.

16. Zilanov V.K. Rossiya - Norvegiya: vozmozhnosti integracii. // Rybnoe hozyajstvo. 1999. № 6. pp.17-19. 
17. Зиланов В.К., Клочков Д.Н. Северной рыбопромысловой разведке - 80 лет: от прошлого к настоящему // Рыбное хозяйство. 2018. № 3. C. $37-48$.

17. Zilanov V.K., Klochkov D.N. Severnoj rybopromyslovoj razvedke - 80 let: ot proshlogo k nastoyashchemu // Rybnoe hozyajstvo. 2018. № 3. pp. 37-48.

18. Сенников С.А. Международные договоры Российской Федерации как правовая основа рыболовства в морском районе архипелага Шпицберген // Евразийский юридический журнал, 2014. № 7 (74). C. 88-91.

18. Sennikov S.A. Mezhdunarodnye dogovory Rossijskoj Federacii kak pravovaya osnova rybolovstva $v$ morskom rajone arhipelaga SHpicbergen // Evrazijskij yuridicheskij zhurnal, , 2014. № 7 (74). pp. 88-91.

19. Сенников С.А., Сенюков В.Л., Шибанов В.Н. Шпицберген в норвежском законодательстве после 1920 г. // Комплексные исследования природы Шпицбергена. - Апатиты, 2005. - Вып. 5: Сборник материалов Пятой международной конференции (Мурманск, октябрь 2005 г.). С. $48-56$.

19. Sennikov S.A., Senyukov V.L., SHibanov V.N. SHpicbergen v norvezhskom zakonodatel'stve posle 1920 g. // Kompleksnye issledovaniya prirody SHpicbergena. - Apatity, 2005. - Vyp. 5: Sbornik materialov Pyatoj mezhdunarodnoj konferencii (Murmansk, oktyabr' 2005 g.). pp. 48-56.

20. Бекяшев К.А. Сможет ли Россия защитить свои права в водах Шпицбергена? - Морское право и политика - М., - 2006. №3 C. 2-10.

20. Bekyashev K.A. Smozhet li Rossiya zashchitit' svoi prava v vodah SHpicbergena? - Morskoe pravo i politika - M., - 2006. №3 pp. 2-10.

21.Криворотов А.К. Международно-правовой статус рыбоохранной зоны вокруг Шпицбергена. // Московский журнал международного права. М., 1994, №3-4. С 96-113.

21.Krivorotov A.K. Mezhdunarodno-pravovoj status ryboohrannoj zony vokrug SHpicbergena. // Moskovskij zhurnal mezhdunarodnogo prava. M., 1994, №3-4. pp 96-113.

22. Криворотов А.К. Неравный раздел пополам: к подписанию российско-норвежского договора о разграничении в Арктике. //Вестник Московского университета. М.,-2011, №2. С.62-91.

22. Krivorotov A.K. Neravnyj razdel popolam: k podpisaniyu rossijskonorvezhskogo dogovora o razgranichenii v Arktike. //Vestnik Moskovskogo universiteta. M.,-2011, №2. pp.62-91.

23. Мелков Г.М. Юридическая оценка Договора между Российской Федерацией и Норвегией. //Рыбные ресурсы. - Мурманск., №42010. C.10-13

23. Melkov G.M. YUridicheskaya ocenka Dogovora mezhdu Rossijskoj Federaciej i Norvegiej. / /Rybnye resursy. - Murmansk., №4-2010. pp.10-13. 24. Geir HØnneland. Hvordan skal Putin ta Barentshavet tilbake? Fagbokforlaget Vigmostad \& BjØrke AS 2014. 152 c.

25. Договор о Шпицбергене от 9 февраля 1020 года. http://docs.cntd. ru/document/902038168.

25. Dogovor o SHpicbergene ot 9 fevralya 1020 goda. http://docs.cntd. $\mathrm{ru} /$ document/902038168.

26.Сборник действующих договоров, соглашений и конвенций, заключенных с иностранными государствами. - М., 1938, вып. IX НКИД. № 322. С. 53-61.

26.Sbornik dejstvuyushchih dogovorov, soglashenij i konvencij, zaklyuchennyh s inostrannymi gosudarstvami. - M., 1938, vyp. IX NKID. № 322. pp. 53-61.

27. Международно-политические условия развития Арктической зоны Российской Федерации.-М.: Магистр. 2015. 304 с.

27. Mezhdunarodno-politicheskie usloviya razvitiya Arkticheskoj zony Rossijskoj Federacii.-M.: Magistr. 2015. 304 p.

28. Вылегжанин А.Н., Зиланов В.К. Шпицберген: правовой режим прилегающих морских пространств. Теория и практика морской деятельности. СОПС. Москва,2006 г. 248 с.

28. Vylegzhanin A.N., Zilanov V.K. SHpicbergen: pravovoj rezhim prilegayushchih morskih prostranstv. Teoriya i praktika morskoj deyatel'nosti. SOPS. Moskva,2006 g. 248 p.

29. Вылегжанин А. Н. Договор о Шпицбергене 1920 года и рыболовство //Рыбное хозяйство, 2000, №5, с. 8-11.

29. Vylegzhanin A. N. Dogovor o SHpicbergene 1920 goda i rybolovstvo // Rybnoe hozyajstvo, 2000, №5, pp. 8-11.

30. Меркурий-клуб. Материалы заседания «Проблемы и перспективы эффективного освоения и развития Арктической зоны и прилегающих регионов России». М., ООО «ТПП-Информ», 2014. 127 с.
30. Merkurij-klub. Materialy zasedaniya «Problemy i perspektivy effektivnogo osvoeniya i razvitiya Arkticheskoj zony i prilegayushchih regionov Rossii». M., OOO «TPP-Inform», 2014. 127 p.

31. Zilanov, V. Mister Russland Arktis? Vidarforlaget AS 2018. 281 c.

32. ПИНРО - на пути к столетию. /Сост. С.С. Дробышева, В.Н. Шлейник. - Мурманск: Изд.-во ПИНРО. 2005. 284 с.

32. PINRO - na puti k stoletiyu. /Sost. S.S. Drobysheva, V.N. SHlejnik. Murmansk: Izd.-vo PINRO. 2005. 284 p.

33. Печеник Л.Н., Шепель Л.И. Некоторые черты биологии полярной тресочки Баренцева моря. Рыбное хоз-во. 1970. № 12. С.13-14.

33. Pechenik L.N., SHepel' L.I. Nekotorye cherty biologii polyarnoj tresochki Barenceva morya. Rybnoe hoz-vo. 1970. № 12. pp.13-14.

34. Низовцев Г.П. Распределение молоди черного палтуса в Баренцевом море и восточной части Норвежского моря // Рыбное хоз-во. 1983a. - № 12. C. 26-28.

34. Nizovcev G.P. Raspredelenie molodi chernogo paltusa v Barencevom more i vostochnoj chasti Norvezhskogo morya // Rybnoe hoz-vo. - 1983a. - № 12. pp. 26-28.

35. Календарь промысла трески в Медвежинско-Шпицбергенском районе в 1995-2000 гг./Сост. Альбиковская Л.К. - Мурманск: Изд.воПИНРО, 2004. 96 с.

35. Kalendar' promysla treski v Medvezhinsko-SHpicbergenskom rajone v 1995-2000 gg./Sost. Al'bikovskaya L.K. - Murmansk: Izd.-voPINRO, 2004. $96 \mathrm{p}$.

36. The Barentssea. Ecosystem, resourses, management. Half a century of Russian-Norwegian cooperation. Tapir Academic Press, Trondheim, Norway. 2011. 825 c.

37. Порцель А.К. Споре о Шпицбергене: точки не поставлены. - Архангельск, журнал Арктика и Север № 3, 2011. С. 1-22.

37. Porcel' A.K. Spore o SHpicbergene: tochki ne postavleny. - Arhangel'sk, zhurnal Arktika i Sever № 3, 2011. pp. 1-22.

38. Порцель А.К. Россия остается на Шпицбергене - Архангельск, журнал Арктика и Север №9, 2011. С. 40-59.

38. Porcel' A.K. Rossiya ostaetsya na SHpicbergene - Arhangel'sk, zhurnal Arktika i Sever №9, 2011. pp. 40-59.

39. Зиланов В.К. Арктическое разграничение России и Норвегии: новые вызовы и сотрудничество. - Архангельск, журнал Арктика и Север №29, 2017.С 28-56.

39. Zilanov V.K. Arkticheskoe razgranichenie Rossii i Norvegii: novye vyzovy i sotrudnichestvo. - Arhangel'sk, zhurnal Arktika i Sever №29, 2017.pp 28-56.

40. Арктический регион: проблемы международного сотрудничества: хрестоматия в 3 т. Т. 3: правовые источники/ гл. ред. И.С. Иванов. М., 2013. С.22.

40. Arkticheskij region: problemy mezhdunarodnogo sotrudnichestva: hrestomatiya v 3t. T. 3: pravovye istochniki/ gl. red. I.S. Ivanov. M., 2013. p. 22. 41. Зиланов В.К. Баренцевоморская ошибка Президента: Международные отношения, управление морскими живыми ресурсами, рыболовство, право и политика/ - Мурманск: Изд-во МГТУ, 2012. 418 с. 41.ZilanovV.K. Barencevomorskaya oshibkaPrezidenta:Mezhdunarodnye otnosheniya, upravlenie morskimi zhivymi resursami, rybolovstvo, pravo i politika/ - Murmansk: Izd-vo MGTU, 2012. 418 p.

42. Студенецкий С.А. Норвегия - Исландия. «Рыбная война» в водах Шпицбергена // Рыбное хозяйство. 2003. № 6. С. 39.

42. Studeneckij S.A. Norvegiya - Islandiya. «Rybnaya vojna» v vodah SHpicbergena // Rybnoe hozyajstvo. 2003. № 6. p. 39.

43. Федоров А.Ф., Злобин В.С., Слободняк В.А. Норвегия: суверенитет над Шпицбергеном или нечто большее? // Рыбное хозяйство. 2005. №6. C.13-15.

43. Fedorov A.F., Zlobin V.S., Slobodnyak V.A. Norvegiya: suverenitet nad SHpicbergenom ili nechto bol'shee? // Rybnoe hozyajstvo. 2005. №6. pp.13-15.

44. Шпицберген: конфликт набирает обороты. // Рыбное хозяйство. 2005. № 6. C. 12.

44. SHpicbergen: konflikt nabiraet oboroty. // Rybnoe hozyajstvo. 2005. № 6. p. 12.

45. Якобсен С., Якобсен Р. Взглянуть глазами русских. // Рыбное хозяйство. 2019. №1. С. 8.

45. YAkobsen S., YAkobsen R. Vzglyanut' glazami russkih. // Rybnoe hozyajstvo. 2019. №1. p. 8.

46. Гнилорыбов Н.А. Угольные шахты на Шпицбергене. - М.: Недра, 1988. $101 \mathrm{c}$.

46. Gnilorybov N.A. Ugol'nye shahty na shpicbergene. - M.: Nedra, 1988. $101 \mathrm{p}$. 